Research Report 1730

\title{
Review of Battle Staff Training Research at Brigade and Battalion Levels
}

\author{
Bruce S. Sterling and Kathleen A. Quinkert \\ U.S. Army Research Institute
}

\section{Armored Forces Research Unit \\ Barbara A. Black, Chief}

U.S. Army Research Institute for the Behavioral and Social Sciences 5001 Eisenhower Avenue, Alexandria, Virginia 22333-5600

December 1998 